\title{
Formation of Complexes of Deoxyribonucleic Acid (DNA) with Copper(II) and Other Bivalent Metal Ions
}

\author{
Hirofusa ShIRAI, Yukinori ITOH, Akio KUROSE, \\ Kenji HanabusA, Koji AbE, and Nobumasa Hojo \\ Department of Functional Polymer Science, \\ Faculty of Textile Science and Technology, \\ Shinshu University, Ueda 386, Japan
}

(Received August 8, 1983)

\begin{abstract}
The complexation of deoxyribonucleic acid (DNA) with $\mathrm{Cu}$ (II) and other bivalent metal ions was studied at relatively low molar ratios of the metal ion to phosphoric acid residues (HL) of DNA $\left(T_{\mathrm{M}^{2}+} / T_{\mathrm{HL}}\right)$ by potentiometry, ultraviolet, visible, infrared and circular dichroism spectrophotometry, and electron spin resonance spectroscopy. $\mathrm{A} \mathrm{Cu}$ (II) ion forms a stable complex with DNA in the $\mathrm{pH}$ region above 7.3. In the $\mathrm{pH}$ region from 4 to 10 , various bivalent metal ions can form complexes with DNA, the complexation ability being in the order of $\mathrm{Cu}(\mathrm{II})>\mathrm{Zn}(\mathrm{II})>\mathrm{Co}(\mathrm{II})>\mathrm{Ni}(\mathrm{II}) \simeq \mathrm{Mg}(\mathrm{II})$. When $T_{\mathrm{Cu}^{2+}} / T_{\mathrm{HL}}$ is lower than 0.33 , the structure of DNA (B-form) does not change by such complexation. $\mathrm{Cu}$ (II) ions are coordinated mainly with the phosphoric acid residues of the same DNA chain. However, this coordination bond is relatively weak.

KEY WORDS DNA / Cu(II)-DNA Complex / Coordination / Conformation / Polymer-Metal Complex /
\end{abstract}

The interaction of DNA with metal ions, especially bivalent metal ions, has aroused interest in relation to the functions of nucleic acids, such as DNA replication, transcription of genetic codes, and enzyme reactions with DNA. ${ }^{1}$ Thus, a number of studies ${ }^{2-18}$ have been carried out on this interaction, the bivalent metal ions treated being $\mathrm{Co}(\mathrm{II}), \mathrm{Ni}(\mathrm{II})$, $\mathrm{Zn}(\mathrm{II}), \mathrm{Mn}(\mathrm{II}), \mathrm{Cu}(\mathrm{II})$, and $\mathrm{Cd}(\mathrm{II})$. Among these ions, the $\mathrm{Cu}(\mathrm{II})$ ion has the strongest complexation ability with DNA, and is mainly coordinated with the base of DNA. ${ }^{2-15}$ However, the experiments have so far concerned molar ratios of total $\mathrm{Cu}(\mathrm{II})$ ions $\left(T_{\mathrm{Cu}^{2+}}\right)$ to monomeric units of DNA $\left(T_{\mathrm{HL}}\right), T_{\mathrm{Cu}^{2}+} / T_{\mathrm{HL}}$, larger than 0.5 . Under such conditions, the metal ions were in excess compared to ligands, so that a uniform coordination was difficult to be realized.

DNA has two kinds of coordination sites, phosphoric acid residues and bases, to bivalent metal ions. When in excess, the metal ions can coordinate with both coordination sites. In most previous reports, it was reasonably assumed that metal ions coordinate with these two sites. Moreover, under such conditions of $T_{\mathrm{Cu}^{2}+} / T_{\mathrm{HL}}$ larger than 0.5 , it is possible that the higher ordered structure of DNA is destroyed. Thus, it is important to discuss each of the two coordination sites separately at relatively low $T_{\mathrm{Cu}^{2}+} / T_{\mathrm{HL}}$.

In a series of papers, ${ }^{19-21}$ we studied the complex formation and coordination structure of several transition metal ions with polymeric ligands such as poly(vinyl alcohol), $\operatorname{poly}(\alpha-$ amino acid)s, and silk proteins. In these reports, we proposed that metal-polymer complexes having a uniform coordination structure may be formed at values of $T_{\mathrm{M}^{2}+} / T_{\mathrm{Ligand}}$ ratio below 0.5 .

The purpose of this paper is to characterize the complex formation of DNA with bivalent 
metal ions, especially $\mathrm{Cu}(\mathrm{II})$ ion, at relatively low values of $T_{\mathrm{M}^{2+}} / T_{\mathrm{HL}}$ by potentiometry, ultraviolet, visible, and infrared spectroscopy, circular dichroism, and electron spin resonance.

\section{EXPERIMENTAL}

\section{Materials}

The DNA sample used was a sodium salt of calf thymus type I DNA purchased from Sigma. The proteins usually contained in commercial DNA were removed by extraction with freshly distilled phenol and reprecipitation from an ethanol solution, both at $4^{\circ} \mathrm{C}$. The reagent used, including copper perchlorate and other inorganic chemicals, were of analytical grade and used without further purification. Partially phosphorylated poly(vinyl alcohol) (phos.-PVA) was prepared in the same way as in our previous paper. ${ }^{22}$ The degree of phosphorylation of phos.-PVA was found to be $30 \%$ by $\mathrm{pH}$ titration.

\section{Formation of $\mathrm{Cu}(\mathrm{II})-\mathrm{DNA}$ and $\mathrm{Cu}(\mathrm{II})-$ Phos.- PVA Complexes}

All solutions were prepared with deionized distilled water. The concentration of DNA was determined from a UV absorption at $260 \mathrm{~nm}$ $(\varepsilon=6600) .^{23}$ The $\mathrm{pH}$ of the solution was controlled by adding aqueous $\mathrm{HCl}$ or $\mathrm{KOH}$. A $\mathrm{Cu}(\mathrm{II})-\mathrm{DNA}$ complex solution $(\mu=0.1$; $\left.\mathrm{KClO}_{4}\right)$ was prepared by adding aqueous $\mathrm{Cu}\left(\mathrm{ClO}_{4}\right)_{2}\left(2 \times 10^{-3}\left(\mathrm{moll}^{-1}\right)\right)$ to $10 \mathrm{ml}$ of aqueous DNA $\left[2.19 \times 10^{-3}(\mathrm{~mol}\right.$ of phosphoric acid residues (abbreviated as $\mathrm{HL}) 1^{-1}$ ). The value of $T_{\mathrm{Cu}^{2+}} / T_{\mathrm{HL}}$ was varied from 0.083 to 0.33 . $5 \mathrm{ml}$ of aqueous $\mathrm{NaClO}_{4}\left(0.8\left(\mathrm{moll}^{-1}\right)\right)$ and $0.01 \mathrm{~N}$ aqueous $\mathrm{NaOH}$ were added to make up a solution of $30 \mathrm{ml}$, and then the $\mathrm{pH}$ of the solution was adjusted to a desired value. This mixture was left standing overnight at $25^{\circ} \mathrm{C}$ in order to complete the complexation reaction. Complexes of DNA with other bivalent metal ions were formed in a similar way, and $\mathrm{Cu}(\mathrm{II})$-phos.-PVA complex solutions were obtained in the same way as mentioned above.

Aqueous solutions of DNA- and phos.PVA-Cu(II) complexes were dialyzed against pure water and cast onto polyethylene films. The films obtained were dried for about three days at room temperature and further dried under vacuum for a few days.

\section{Measurements}

$\mathrm{pH}$ values of the complex solutions were measured within an accuracy of 0.05 by an Orion Research Model 701A digital potentiometer after the solutions had stood for at least $24 \mathrm{~h}$.

Spectrophotometric measurements were carried out at $25^{\circ} \mathrm{C}$ by a JASCO UVIDEC-505 type spectrophotometer with a $5 \mathrm{~cm}$ quartz cell. Circular dichroism (CD) was measured by a JASCO J-40A CD spectrophotometer at room temperature using a $1 \mathrm{~mm}$ quartz cell. Infrared (IR) spectra of the complex films were obtained using a JASCO IR-A type spectrophotometer.

Viscosities of the complex solutions were measured by a Ubbelohde viscometer at 25 $( \pm 0.05){ }^{\circ} \mathrm{C}$.

Electron spin resonance (ESR) spectra of $\mathrm{Cu}(\mathrm{II})-\mathrm{DNA}$ and $\mathrm{Cu}(\mathrm{II})$-phos.-PVA complexes were measured at room temperature by a Varian E-102 type X-band spectrometer with $100 \mathrm{kHz}$ field modulation. The microwave frequency was $9.521 \mathrm{GHz}$, the microwave power, $5 \mathrm{~mW}$ for complex films and $12.5 \mathrm{~mW}$ for complex solutions, and the modulation amplitude, $8 \mathrm{G}$. The samples were placed in a quartz tube of $2 \mathrm{~mm}$ in inner diameter.

\section{RESULTS AND DISCUSSION}

\section{Complex Formation of DNA with Bivalent Metal Ions}

The $\mathrm{pH}$ titration curves for aqueous solutions of DNA and DNA-bivalent metal ion complexes are shown in Figure 1, along with that for aqueous $\mathrm{Cu}\left(\mathrm{NO}_{3}\right)_{2}$. In this figure, $\alpha$ 


\section{DNA-Cu(II) Complex}

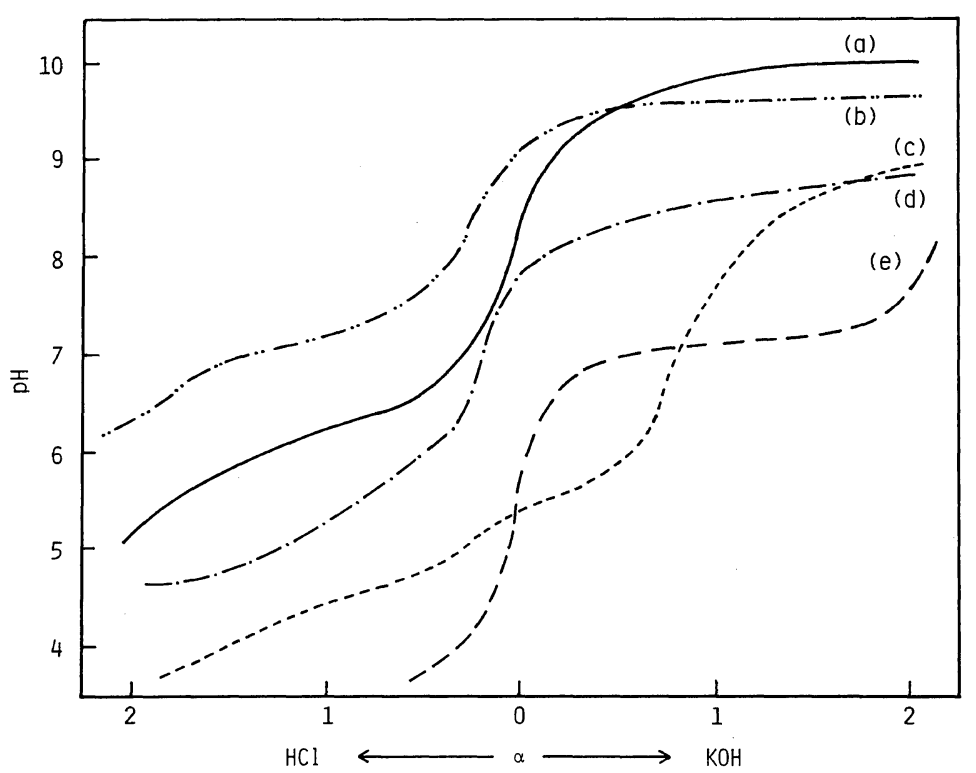

Figure 1. Potentiometric titrations of aqueous $\mathrm{DNA}, \mathrm{Cu}\left(\mathrm{NO}_{3}\right)_{2}$ and $\mathrm{DNA}$-bivalent metal ion complexes: $\alpha=[\mathrm{KOH}]($ or $[\mathrm{HCl}]) /\left[\mathrm{M}^{2+}\right] ; T_{\mathrm{M}^{2}+} / T_{\mathrm{HL}}=0.2 ; \mu=0.1\left(\mathrm{KClO}_{4}\right) ;[\mathrm{DNA}]=1.81 \times 10^{-3}$ (unit mol1 ${ }^{-1}$ ) at room temperature. (a) DNA; (b) Ni(II)-DNA; (c) Cu(II)-DNA; (d) Co(II)-DNA; (e) $\mathrm{Cu}\left(\mathrm{NO}_{3}\right)_{2}$.

denotes the molar ratio of added $\mathrm{KOH}$ or $\mathrm{HCl}$ to metal ion, HL the phosphoric acid residue of DNA, and $T_{\mathrm{M}^{2}}$ and $T_{\mathrm{HL}}$ the total molar concentrations of metal ions and $\mathrm{HL}$, respectively. The $\mathrm{pH}$ of an aqueous DNA $\left(\mu=0.1 ; \mathrm{KClO}_{4}\right)$ was lowered by the addition of aqueous $\mathrm{Cu}\left(\mathrm{ClO}_{4}\right)_{2}$, whose $\mathrm{pH}$ was the same as that of aqueous DNA. The $\mathrm{Cu}$ (II)-DNA complex solution showed the lowest $\mathrm{pH}$ titration curve over a wide range of $\mathrm{pH}$ among those for mixed solutions of bivalent metal ions and DNA. This indicates that protons are released from $\mathrm{HL}$ as a result of complexation of DNA with $\mathrm{Cu}$ (II) ions. The degree of proton release estimated from the titration curves obtained showed that the complexation ability of a bivalent metal ion with DNA under our experimental conditions is in the order of $\mathrm{Cu}(\mathrm{II})>\mathrm{Zn}$ (II) $>\mathrm{Co}$ (II) $>\mathrm{Ni}$ (II) $\simeq \mathrm{Mg}$ (II) . Sigel et $a l .{ }^{24}$ studied the complex formation between these bivalent metal ions and adenosine 5'-triphosphate (ATP) under the conditions $\mu=0.1$ and $T_{\mathrm{M}^{2}+} / T_{\mathrm{HL}}<1.0$, and found the same results as ours with HL. Since the complexes formed between bivalent metal ions and ligands with amino groups are generally stabler in the order of $\mathrm{Cu}$ (II) $>\mathrm{Ni}$ (II) $>$ $\mathrm{Co}(\mathrm{II})>\mathrm{Zn}(\mathrm{II}),{ }^{25}$ we see that these metal ions coordinate $\mathrm{HL}$ rather than bases of the DNA chain. The coordination number, coordination structure, and equilibrium constants cannot be determined only by these titration curves, since there are two kinds of coordination sites on the DNA chain (HL and bases) and the interaction between a metal ion and DNA is relatively weak. This will be discussed in detail in a later part of this paper.

Figure 2 shows the electronic spectra (500$850 \mathrm{~nm}$ ) for $\mathrm{Cu}(\mathrm{II})-\mathrm{DNA}$ complex solutions $\left(T_{\mathrm{Cu}^{2}+} / T_{\mathrm{HL}}=0.2\right)$ at different $\mathrm{pH}$. A new broad band appeared at about $600-800 \mathrm{~nm}$ when $\mathrm{Cu}$ (II) ions were added to aqueous DNA. When the $\mathrm{pH}$ of the solution was lower than 6.3 , the wavelength at the peak of this broad band $\left(\lambda_{\max }\right)$ was $740 \mathrm{~nm}$ and independent of $\mathrm{pH}$. With an increase in $\mathrm{pH}$, however, $\lambda_{\max }$ shifted to a shorter wavelength and the absorbance at $\lambda_{\max }\left(D_{\max }\right)$ increased simultaneously. At $\mathrm{pH}$ 


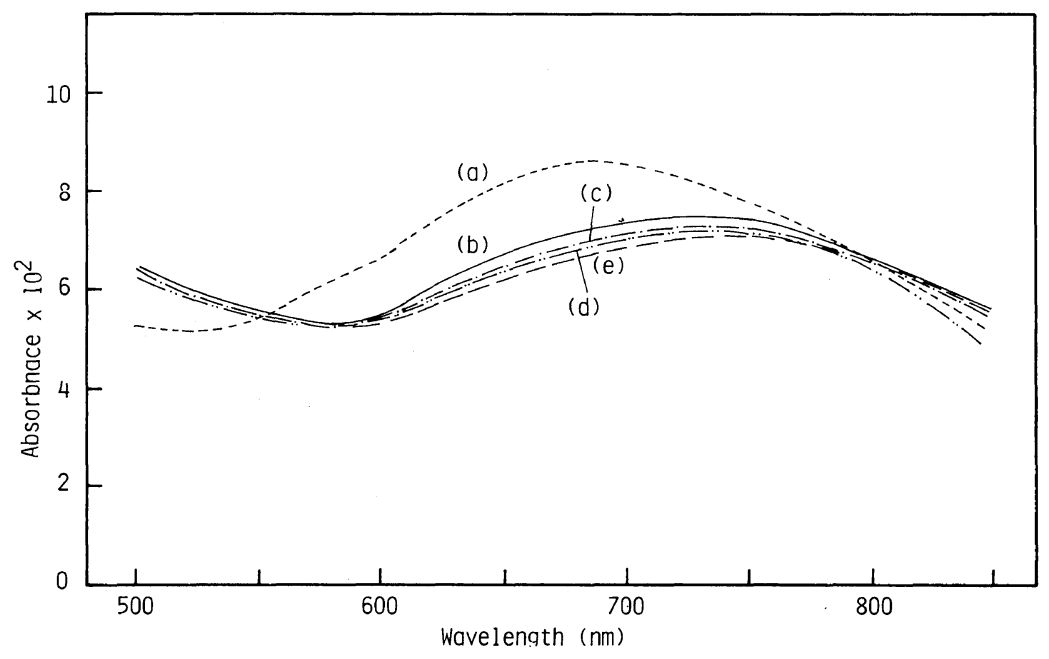

Figure 2. Electronic spectra of $\mathrm{Cu}(\mathrm{II})-\mathrm{DNA}$ complexes in aqueous solutions of different $\mathrm{pH}: T_{\mathrm{Cu}^{2}+} /$ $T_{\mathrm{HL}}=0.2 ; \mu=0.1\left(\mathrm{KClO}_{4}\right) ;[\mathrm{DNA}]=1.50 \times 10^{-3}$ (unit moll $\left.{ }^{-1}\right)$ at room temperature; cell length $=5 \mathrm{~cm}$. (a) $\mathrm{pH}=7.28$; (b) $\mathrm{pH}=6.82$; (c) $\mathrm{pH}=6.53$; (d) $\mathrm{pH}=6.43$; (e) $\mathrm{pH}=6.30$.

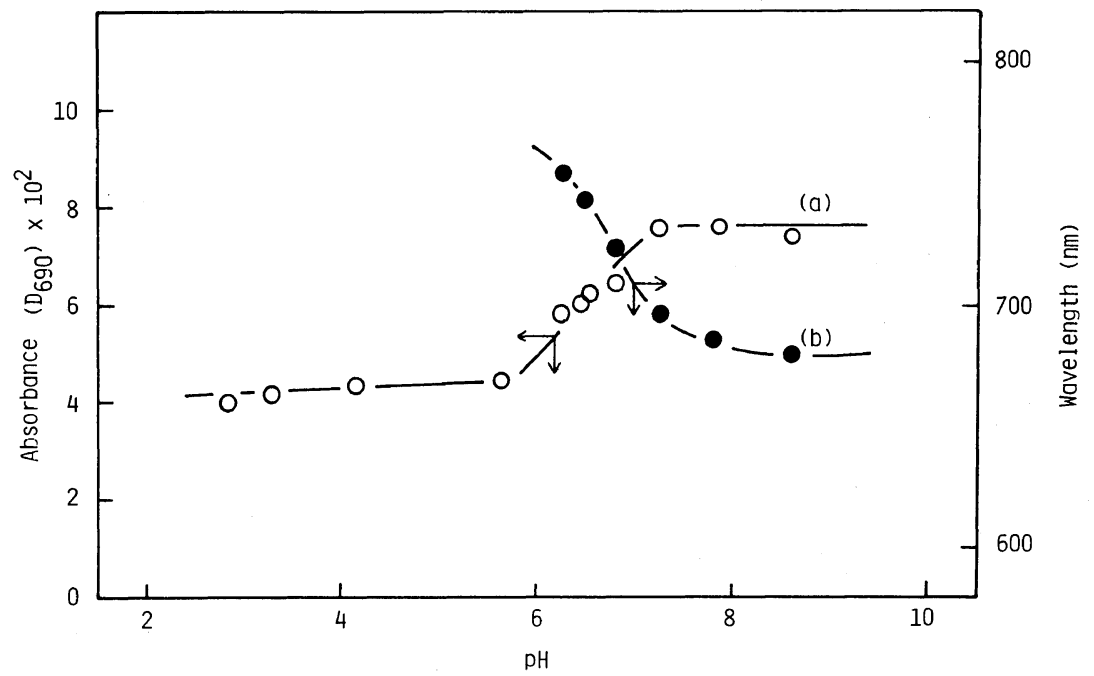

Figure 3. $\mathrm{pH}$ dependence of $D_{690}$ and $\lambda_{\max }$ for $\mathrm{Cu}(\mathrm{II})-\mathrm{DNA}$ complexes in aqueous solution: $T_{\mathrm{Cu}^{2}+} / T_{\mathrm{HL}}=$ $0.2 ; \mu=0.1\left(\mathrm{KClO}_{4}\right) ;[\mathrm{DNA}]=1.50 \times 10^{-3}$ (unit moll ${ }^{-1}$ ) at room temperature; cell length $=5 \mathrm{~cm}$. (a) $D_{690}$; (b) $\lambda_{\max }$.

7.3, $\lambda_{\max }$ was observed at about $690 \mathrm{~nm}$. A further increase in $\mathrm{pH}$ did not affect $\lambda_{\max }$ and $D_{\text {max }}$.

The $\mathrm{pH}$ dependence of $\lambda_{\max }$ and the absorbance at $690 \mathrm{~nm}\left(D_{690}\right)$ is shown in Figure 3. $\lambda_{\max }$ and $D_{690}$ changed in the $\mathrm{pH}$ region from 6.3 to 7.3 , and were constant for other $\mathrm{pH}$.
These results indicate that no complex was formed at $\mathrm{pH}$ below 6.3 and a stable complex of $\mathrm{Cu}(\mathrm{II})$-DNA was formed at $\mathrm{pH}$ above 7.3.

The molecular extinction coefficient $(\varepsilon)$ for the $\mathrm{Cu}(\mathrm{II})$-DNA complex calculated from the $D_{690}$ value at $\mathrm{pH}=8.0$ was about 60 $\left(1 \mathrm{~mol}^{-1} \mathrm{~cm}^{-1}\right)$. This $\varepsilon$ value and $\lambda_{\max }$ allow the 


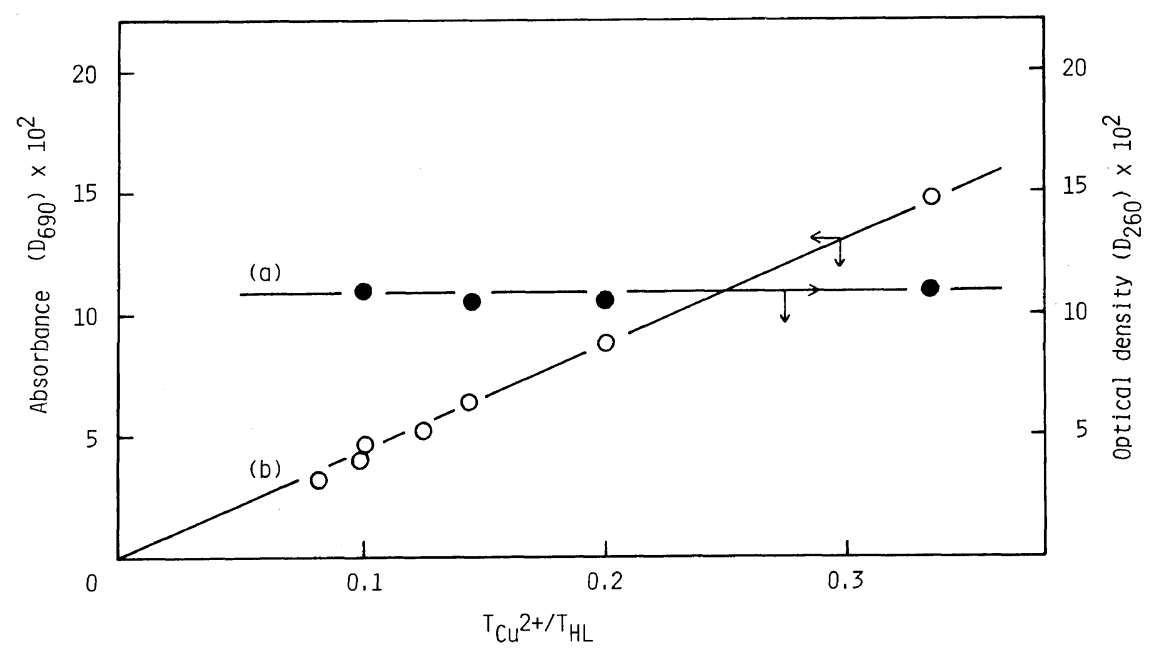

Figure 4. Relationship between absorbance $\left(D_{260}\right.$ and $\left.D_{690}\right)$ and $T_{\mathrm{Cu}^{2}+} / T_{\mathrm{HL}}$ in $\mathrm{Cu}(\mathrm{II})-\mathrm{DNA}$ complexes in aqueous solution: $\mathrm{pH}=8.0 ; \mu=0.1\left(\mathrm{KClO}_{4}\right) ;[\mathrm{DNA}]=1.76 \times 10^{-3}\left(\right.$ unit moll $\left.^{-1}\right)$ at room temperature; cell length $=5 \mathrm{~cm}$ for $D_{690}$ and $1 \mathrm{~cm}$ for $D_{260}$. (a) $D_{260}$; (b) $D_{690}$.

absorption band to be assigned to a $d-d$ absorption band of the coordinated $\mathrm{Cu}(\mathrm{II})$ ion. In general, $\lambda_{\max }$ for the $d-d$ absorption band of a $\mathrm{Cu}$ (II) ion coordinated with nitrogen atoms is located at a wavelength shorter than $650 \mathrm{~nm}$. $\lambda_{\max }$ of a $\mathrm{Cu}(\mathrm{II})$ ion coordinated with oxygen atoms of the HL of partially phosphorylated poly(vinyl alcohol) (phos.-PVA) was found between 700 and $800 \mathrm{~nm} .{ }^{22}$ The value of $\varepsilon$ in the $\mathrm{Cu}(\mathrm{II})$-DNA system was comparable to that of the $\mathrm{Cu}(\mathrm{II})$-phos.-PVA complex system. It was reported that in the $\mathrm{Cu}$ (II)-ATP system, ${ }^{24} \lambda_{\max }$ of the $d-d$ absorption band was about $670 \mathrm{~nm}$. Therefore, it may be concluded that $\mathrm{Cu}(\mathrm{II})$ ions are coordinated with the $\mathrm{HL}$ of DNA. The result that $\lambda_{\max }$ was observed at a relatively long wavelength suggests that the $\mathrm{Cu}$ (II) ion is coordinated tetragonally with four oxygen atoms of the HL of DNA.

Figure 4 shows the absorbance at $260 \mathrm{~nm}$ $\left(D_{260}\right)$ and $D_{690}$ as a function of $T_{\mathrm{Cu}^{2}+} / T_{\mathrm{HL}}$ in the $\mathrm{Cu}(\mathrm{II})-\mathrm{DNA}$ system at $\mathrm{pH}=8.0$. The value of $D_{690}$ is proportional to $T_{\mathrm{Cu}^{2}+} / T_{\mathrm{HL}}$, indicating that a quantitative complex formation occurs up to $T_{\mathrm{Cu}^{2}+} / T_{\mathrm{HL}}=0.33$. In contrast, the absorbances at the $d-d$ absorption bands of $\mathrm{Cu}$ (II) and $\mathrm{Ni}$ (II) ions coordinated with fibroin or other flexible polymeric ligands are usually proportional to $T_{\mathrm{M}^{2}+} / T_{\text {Ligand }}$ in the region below 0.125 , and then level off. ${ }^{26,27}$ This fact was attributed to the steric hindrance of a flexible polymer chain and/or to the decrease in concentration of active coordination sites due to neighboring inactive residues. Since DNA maintains a double helical structure (B-form under our experimental conditions), the effect of the steric hindrance on the complex formation may not be important. Therefore, more $\mathrm{Cu}(\mathrm{II})$ ions may have a greater tendency to associate with DNA than the more flexible polymeric ligands. On the other hand, $D_{260}$ was independent of $T_{\mathrm{Cu}^{2}+} / T_{\mathrm{HL}}$, indicating that the concentration of DNA could be determined from $D_{260}$ even in the presence of $\mathrm{Cu}(\mathrm{II})$ ions.

Figure 5 shows the effects of added $\mathrm{Mg}$ (II) ions on the $\mathrm{Cu}(\mathrm{II})-\mathrm{DNA}$ complex formation. The value of $D_{690}$ which reflects the coordination bonding of $\mathrm{Cu}(\mathrm{II})$ ions with the $\mathrm{HL}$ of DNA decreased gradually with an increase in $\mathrm{Mg}(\mathrm{II})$ ion concentration. This suggests that the coordination bonding between $\mathrm{Cu}$ (II) ions and the HL of DNA are broken by the addition of $\mathrm{Mg}(\mathrm{II})$ ions. In other words, $\mathrm{Mg}(\mathrm{II})$ 


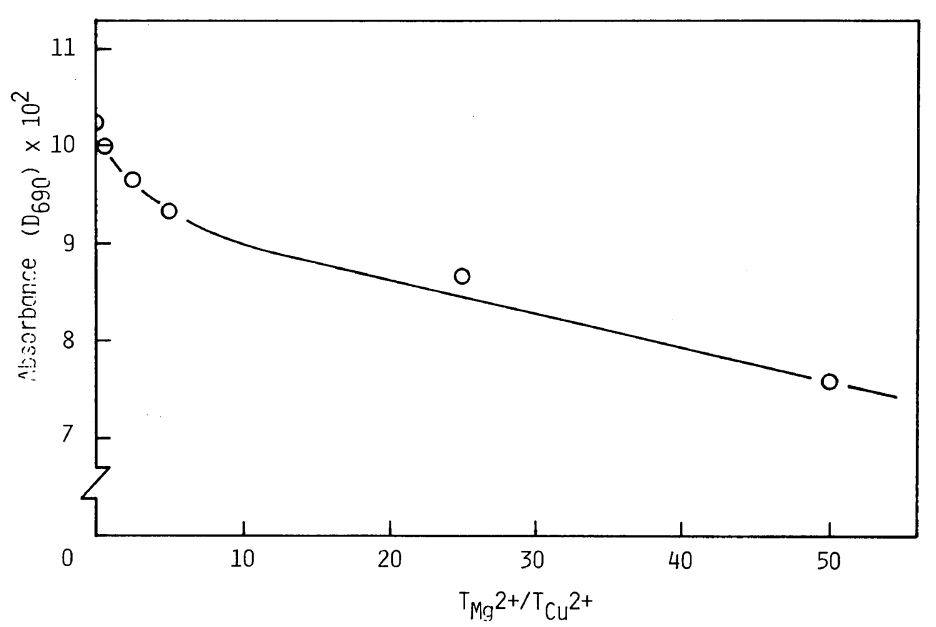

Figure 5. Effects of added $\mathrm{Mg}(\mathrm{II})$ ions on the complex formation of $\mathrm{Cu}(\mathrm{II})$ with $\mathrm{DNA} ; T_{\mathrm{Cu}^{2}+} / T_{\mathrm{HL}}=0.2$; $\mathrm{pH}=8.0 ;[\mathrm{DNA}]=4.55 \times 10^{-3}$ (unit $\mathrm{moll}^{-1}$ ) at room temperature; cell length $=5 \mathrm{~cm}$.

and $\mathrm{Cu}(\mathrm{II})$ ions can be competitively coordinated with the HL of DNA at the same time. However, since the strength of coordination bonding between $\mathrm{Mg}(\mathrm{II})$ ions and the $\mathrm{HL}$ of DNA was much weaker than that between $\mathrm{Cu}$ (II) ion and the HL of DNA, much more $\mathrm{Mg}(\mathrm{II})$ ions than $\mathrm{Cu}(\mathrm{II})$ ions were necessary to exchange metal ions of the complex with DNA. When the concentrations of $\mathrm{Mg}$ (II) and $\mathrm{Cu}$ (II) ions were comparable, the latter ions were preferentially coordinated with the HL of DNA. Thus, the interaction between $\mathrm{Cu}(\mathrm{II})$ ions and the HL of DNA is relatively weak and an electrostatic interaction between the $\mathrm{HL}$ of DNA and $\mathrm{Cu}(\mathrm{II})$ ions also operates in complex formation of DNA with $\mathrm{Cu}$ (II) ions. This is in contrast to the fact that a metalexchange reaction occurred with difficulty in a system consisting of $\mathrm{Cu}$ (II) and $\mathrm{Mg}$ (II) ions and polymeric ligands containing amino groups. Therefore, it is apparent that $\mathrm{Cu}$ (II) ions interact mainly with the HL of DNA.

For the formation of coordination bonds between the bases of DNA and bivalent metal ions, it seems necessary that hydrogen bonds between the bases and/or base stackings be destroyed and the double helical structure of DNA be deformed. If this is the case, bivalent metal ions may be advantageous to coordinate preferentially with the HL of native DNA. When the double helical structure of DNA is destroyed, the bases become free, and coordinate preferentially bivalent metal ions, since the equilibrium constant for the coordination between a bivalent metal ion and the base of DNA is larger than that between a bivalent metal ion and the HL of DNA.

\section{Coordination Structure of $\mathrm{Cu}(\mathrm{II})-\mathrm{DNA}$ Com- plex}

The circular dichroism (CD) spectra of DNA and $\mathrm{Cu}$ (II)-DNA complexes are shown in Figure 6. Under our experimental conditions, DNA takes on the B-form structure, as can be seen from a negative peak around $245 \mathrm{~nm}$, a positive peak around $280 \mathrm{~nm}$, and the difference between the molar extinction coefficients for left- and right-handed circular polarized light $\left(\Delta \varepsilon=\varepsilon_{\mathrm{L}}-\varepsilon_{\mathrm{R}} ;\right.$ units in $1 \mathrm{~mol}^{-1} \mathrm{~cm}^{-1}$ ) at these peaks. ${ }^{28}$ When $\mathrm{Cu}(\mathrm{II})$ ions were added to aqueous DNA, CD spectra essentially remained unchanged. Moreover, the reduced viscosity of aqueous DNA changed only slightly by the addition of $\mathrm{Cu}$ (II) ions, in marked contrast to a drastic decrease in reduced viscosity occurring a sys- 
tem consisting of flexible polymeric ligands and $\mathrm{Cu}(\mathrm{II})$ ions. Thus, the double helical structure, B-form, of DNA undergoes no

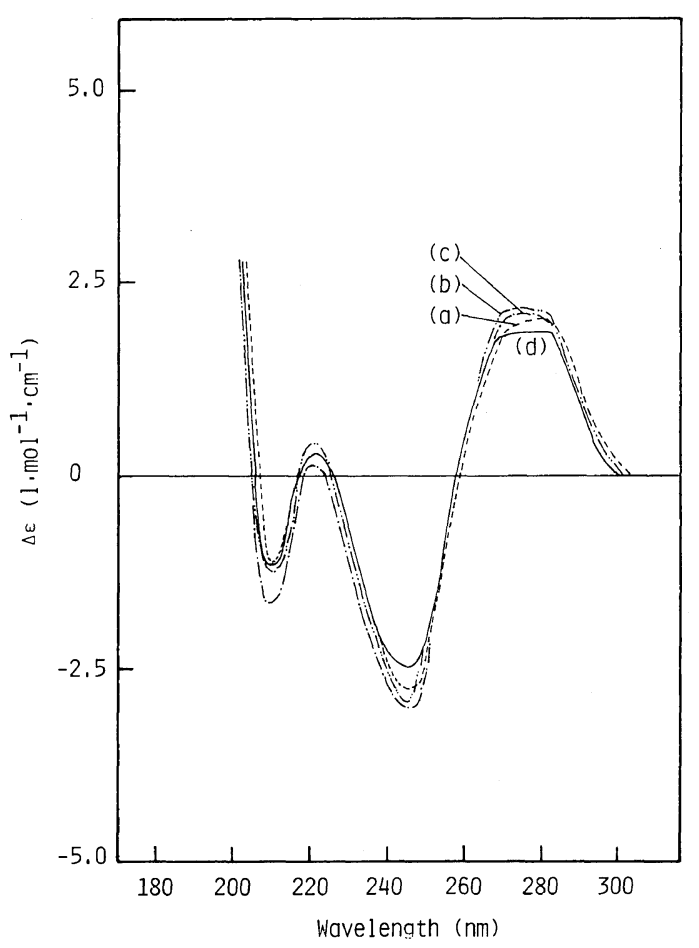

Figure 6. Circular dichroism spectra of DNA and $\mathrm{Cu}$ (II)-DNA complexes in aqueous solution: $\mathrm{pH}=8.0$; $\mu=0.1\left(\mathrm{KClO}_{4}\right) ;[\mathrm{DNA}]=1.76 \times 10^{-3}$ (unit moll ${ }^{-1}$ ) at room temperature. (a) $T_{\mathrm{Cu}^{2}+} / T_{\mathrm{HL}}=0.33$; (b) $T_{\mathrm{Cu}^{2}+} / T_{\mathrm{HL}}=$ 0.2 ; (c) $T_{\mathrm{Cu}^{2}+} / T_{\mathrm{HL}}=0.14$; (d) DNA. substantial changes by complexation with $\mathrm{Cu}$ (II) ions under the experimental conditions that $T_{\mathrm{Cu}^{2}+} / T_{\mathrm{HL}}<0.33$ and $\mu=0.1$. If a $\mathrm{Cu}$ (II) ion is coordinated with four oxygen atoms of more than two HL of different DNA chains, the reduced viscosity may increase because of cross-linking. Therefore, most $\mathrm{Cu}$ (II) ions are considered to be coordinated with the HL on the same DNA chain. According to Förster et al., ${ }^{29}$ the structure of DNA is destroyed by complexation with $\mathrm{Cu}$ (II) ions. However, their experiments were done at relatively low ionic strengths, e.g., lower than $\mu=0.01$, and higher $T_{\mathrm{M}^{2}+} / T_{\mathrm{HL}}$ than in ours. In our work, because the ionic strength was higher, the strength of the coordination bonds was weaker, so that the structure of DNA was not destroyed.

Figure 7 shows infrared absorption spectra of $\mathrm{Cu}(\mathrm{II})-\mathrm{DNA}$ complex film. Differing from DNA, absorption peaks appear at 1170 $\left(\mathrm{cm}^{-1}\right), 1075\left(\mathrm{~cm}^{-1}\right), 988\left(\mathrm{~cm}^{-1}\right)$, and 900 $\left(\mathrm{cm}^{-1}\right)$. By comparison with the IR spectra of $\mathrm{Cu}$ (II)-phos.-PVA complex film, these peaks may be assigned to $v_{\mathrm{P}=\mathrm{O}}\left(1170 \mathrm{~cm}^{-1}\right), v_{\mathrm{P}-\mathrm{O}}$ (1075 and $\left.988 \mathrm{~cm}^{-1}\right)$, and chelate ring deflection $\left(900 \mathrm{~cm}^{-1}\right)$, respectively. Therefore, it may be concluded that $\mathrm{Cu}$ (II) ions are coordinated with the HL of DNA.

$\mathrm{X}$-Band electron spin resonance spectra

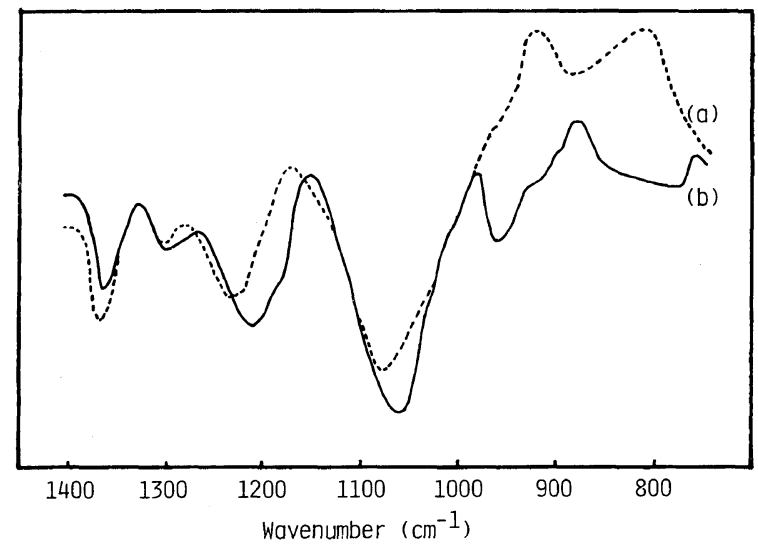

Figure 7. Infrared spectra of DNA and $\mathrm{Cu}(\mathrm{II})-\mathrm{DNA}$ complex films: $T_{\mathrm{Cu}^{2+}} / T_{\mathrm{HL}}=0.2$. (a) $\mathrm{Cu}(\mathrm{II})-\mathrm{DNA}$; (b) DNA. 


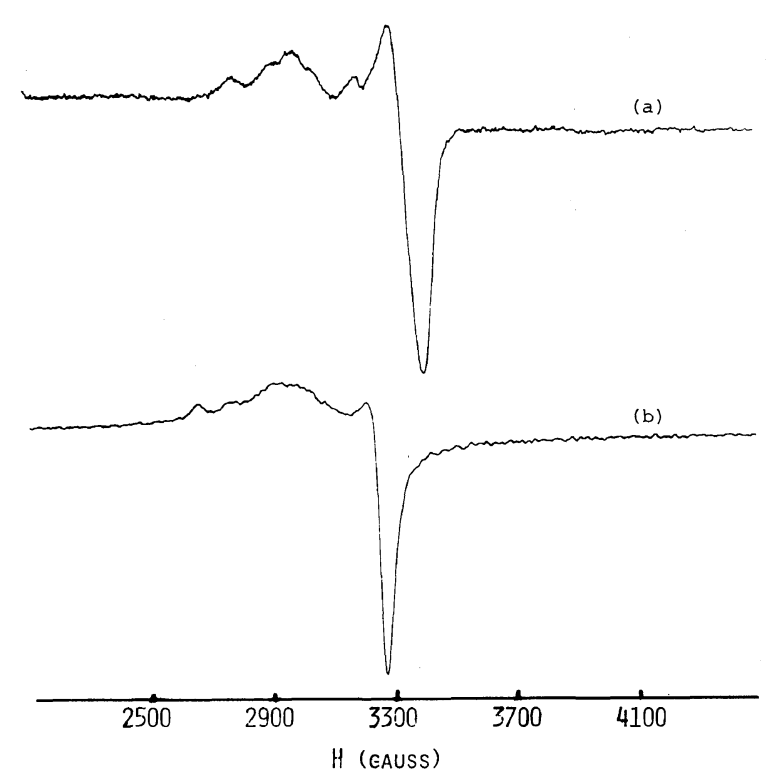

Figure 8. X-Band ESR spectra of $\mathrm{Cu}(\mathrm{II})-\mathrm{DNA}$ and $\mathrm{Cu}(\mathrm{II})$-phos.-PVA complex films: $T_{\mathrm{Cu}^{2}+} / T_{\mathrm{HL}}=0.1$ at room temperature. (a) $\mathrm{Cu}(\mathrm{II})-\mathrm{DNA}$; (b) $\mathrm{Cu}$ (II)-phos.-PVA.

(ESR) of $\mathrm{Cu}(\mathrm{II})-\mathrm{DNA}$ and $\mathrm{Cu}(\mathrm{II})$-phos.-PVA complex films are shown in Figure 8. The apparent $g$ values $\left(g_{\perp}\right)$ of $\mathrm{Cu}(\mathrm{II})-\mathrm{DNA}$ and $\mathrm{Cu}(\mathrm{II})$-phos.-PVA complexes were 2.08 and 2.09 , respectively. The apparent $g$ value of the $\mathrm{Cu}$ (II)-DNA complex solution, $T_{\mathrm{Cu}^{2}+} / T_{\mathrm{HL}}=$ $0.10, \mu=0.1\left(\mathrm{NaClO}_{4}\right), \mathrm{pH}=2.8$, where no complex was formed, was comparable to the value at $\mathrm{pH}=8.0$ (other experimental conditions were the same), in which the formation of $\mathrm{Cu}$ (II)-DNA complex may be complete. From this result, it may be concluded that the coordination bond of $\mathrm{Cu}(\mathrm{II})-\mathrm{DNA}$ is very weak. When $\mathrm{Cu}$ (II) ions are coordinated with imidazolyl groups, the $g_{\perp}$ value is smaller than 2.06. ${ }^{30}$ Similarly, if $\mathrm{Cu}(\mathrm{II})$ ions are coordinated with the bases of DNA, a $g_{\perp}$ value smaller than 2.06 may be obtained. Thus, $\mathrm{Cu}$ (II) ions are considered to be coordinated with the HL of DNA. The hyperfine structure in the $g_{\perp}$ region was not apparent and a $g_{\|}$value higher than the $g_{\perp}$ value was obtained. These results suggest that the tetragonal coordination structure of the $\mathrm{Cu}$ (II)-DNA complex is formed under the present experimental conditions. The ESR spectrum of a $\mathrm{Cu}$ (II)-phos.-PVA complex was very similar to that of the $\mathrm{Cu}(\mathrm{II})-\mathrm{DNA}$ complex. These findings indicate that $\mathrm{Cu}$ (II) ions are coordinated relatively weakly with the HL of DNA.

Many different results have been reported in regard to the complex formation of bivalent metal ions with DNA. ${ }^{2-18}$ Differences in the species of bivalent metal ions, the source and structure of DNA, and the experimental conditions such as $\mathrm{pH}, T_{\mathrm{M}^{2+}} / T_{\mathrm{HL}}$ and ionic strength may account for these difference.

\section{CONCLUSION}

In this study, the coexistence of two coordination structures and the conformational change of DNA were eliminated by choosing the experimental conditions as $T_{\mathrm{M}^{2+}} / T_{\mathrm{HL}}<$ 0.33 and $\mu=0.1$. The following results were obtained: (1) Bivalent metal ions are coordinated preferentially with four oxygen atoms of more than two HL of the same DNA chain instead of the bases of DNA, probably in a tetragonal arrangement. (2) The coordina- 


\section{DNA-Cu(II) Complex}

tion force is relatively weak. (3) The structure of DNA (B-form) does not change on complexation. (4) Complexation of bivalent metal ions with DNA is enhanced in the order of $\mathrm{Cu}(\mathrm{II})>\mathrm{Zn}(\mathrm{II})>\mathrm{Co}(\mathrm{II})>\mathrm{Ni}(\mathrm{II})$ $\simeq \mathrm{Mg}(\mathrm{II})$.

Acknowledgment. This work was partially supported by a Grant-in-Aid for Scientific Research (No. 255341) from the Ministry of Education, Science, and Culture of Japan.

\section{REFERENCES}

1. G. L. Eichhorn, "Inorganic Biochemistry," Vol. 2, Elsevier, Amsterdam, 1973, p 1210.

2. H. Richard, J. P. Schreiber, and M. Daune, Biopolymers, 12, 1 (1973).

3. Ch. Zimmer, G. Luck, H. Fritzche, and H. Triebel, Biopolymers, 10, 441 (1971).

4. J. M. Rifkind, Y. A. Shin, J. M. Heim, and G. L. Eichhorn, Biopolymers, 15, 1879 (1976).

5. H. Venner and Ch. Zimmer, Biopolymers, 4, 321 (1966).

6. J. P. Schreiber and M. Daune, Biopolymers, 8, 139 (1969).

7. P. Zbgniew, Rocz. Chem., 50, 13 (1976).

8. P. Zbgniew, Rocz. Chem., 51, 11 (1977).

9. P. M. Lausarot and R. P. Ferrari, Inorg. Chim. Acta, 33, 145 (1979).

10. D. Bach and I. R. Miller, Biopolymers, 5, 161 (1967).

11. J. H. Coates, D. O. Jordan, and V. K. Srivastava, Biochim. Biophys. Res. Commun., 20, 611 (1965).

12. L. R. Holman and D. O. Jordan, Biopolymers, 11, 1661 (1972).
13. G. L. Eichhorn and P. Clark, Proc. Natl. Acad. Sci., 53, 586 (1965).

14. V. G. Bregadze, E. S. Gelagutashvili, and M. G. Kharatishvili, Stud. Biophys., 67, 25 (1978).

15. A. A. Akhrem, V. A. Sorokin, G. O. Gladchenko, and D. Yu. Lando, Dokl. Akad. Nauk, USSR, 23, 1133 (1979).

16. V. K. Srivastava, P. K. Banerji, and G. P. Srivastava, Rev. Roumaine Chim., 23, 1049 (1978).

17. G. L. Eichhorn and Y. A. Shin, J. Am. Chem. Soc., 90, 7323 (1968).

18. S. Hirai, J. Mol. Biol., 11, 672 (1965).

19. N. Hojo, H. Shirai, and S. Hayashi, J. Polym. Sci., Polym. Symp. Ed., 47, 229 (1974).

20. N. Hojo, H. Shirai, Y. Chujo, and S. Hayashi, $J$. Polym. Sci., Polym. Lett. Ed., 16, 447 (1978).

21. N. Hojo, K. Fukatsu, and T. Hayakawa, Nippon Kagaku Zasshi, 90, 823 (1969).

22. A. Kurose, K. Sugiyama, H. Shirai, S. Hayashi, and N. Hojo, Kobunshi Ronbunshu, 37, 657 (1980).

23. D. S. Studdert, M. Patroni, and R. C. Davis, Biopolymers, 11, 761 (1972).

24. H. Sigel and C. F. Naumann, J. Am. Chem. Soc., 98, 730 (1976).

25. E. Tsuchida and H. Nishide, Adv. Polym. Sci., 24, 1 (1977).

26. H. Shirai and N. Hojo, Nippon Kagaku Kaishi, 1975, 2233.

27. J. Takahashi, H. Shirai, A. Kurose, F. Shimizu, and N. Hojo, Kobunshi Ronbunshu, 39, 745 (1982).

28. V. I. Ivanov, L. E. Minchenkova, A. K. Schyolkina, and A. I. Poletayev, Biopolymers, 12, 89 (1973).

29. W. Förster, E. Bauer, H. Schutz, H. Bera, N. K. Akimenko, L. E. Minchenkova, Yu. M. Evdokimov, and Ya. M. Varshavsky, Biopolymers, 18, 625 (1979).

30. M. Sato, K. Kondo, and K. Takemoto, Makromol. Chem., 179, 601 (1978). 